\title{
Antiproliferative and antimigratory activities of bisphosphonates in human breast cancer cell line MCF-7
}

\author{
BENJAPORN BURANRAT $^{1}$ and SUPAVADEE BOOTHA ${ }^{2}$ \\ ${ }^{1}$ Faculty of Medicine, Mahasarakham University, Maha Sarakham 44000; \\ ${ }^{2}$ School of Pharmaceutical Sciences, University of Phayao, Phayao 56000, Thailand
}

Received April 4, 2018; Accepted April 5, 2019

DOI: $10.3892 / \mathrm{ol} .2019 .10438$

\begin{abstract}
Bisphosphonates (BPs) are antiresorptive drugs that act as effective inhibitors of cancer cell proliferation. However, not all bisphosphonates are equally effective against breast cancer cells in vitro. The present study investigated the extent to which three BPs decrease the viability of MCF-7 human breast cancer cells, stimulate cell apoptosis and inhibit cell migration by modulating proteins in the mevalonate pathway. The three BPs exerted direct anticancer effects against MCF-7 cells in a doseand time-dependent manner, with pamidronate demonstrating the highest efficacy. In addition, the BPs inhibited colony formation ability. The activity of BPs against MCF-7 cells was inhibited by the mevalonate product geranylgeranyl pyrophosphate, which was potentiated by doxorubicin. It was also identified that BPs modulated Ras-related C3 botulinum toxin substrate 1, Ras homolog gene family member $\mathrm{A}$ and cell division control protein 42 homolog gene expression. Consistent with the observed growth inhibitory effects, BPs also inhibited the cell cycle by promoting G1 phase arrest and the downregulation of cyclin D1 and upregulation of $\mathrm{p} 21$. Additionally, BPs were revealed to induce reactive oxygen species expression, caspase- 3 activity and increase the mitochondrial transmembrane potential, which was associated with apoptosis. BP-induced cancer cell apoptosis was detected by acridine orange/ethidium bromide staining and flow cytometry analysis, and was identified to be associated with the induction of caspase- 3 and cytochrome c protein expression. Furthermore, BPs significantly decreased cancer cell migration in a dose-dependent manner and reduced matrix metallopeptidase- 9 protein expression. In summary, the current study demonstrated that BPs exhibited a direct anticancer effect and an antimigratory effect on MCF-7 cells. These findings suggest that BPs may be developed as a therapeutic option for breast cancer and may serve as sensitizing chemotherapeutic agents.
\end{abstract}

Correspondence to: Dr Benjaporn Buranrat, Faculty of Medicine, Mahasarakham University, 296 Nakhornsawan Road, Talad, Muang, Maha Sarakham 44000, Thailand

E-mail: buranrat@gmail.com

Key words: bisphosphonate, alendronate, risedronate, pamidronate, migration, apoptosis

\section{Introduction}

Bisphosphonates (BPs) are C-substituted pyrophosphate analogs used to treat and prevent osteoporosis, cancer and bone metastasis $(1,2)$. BPs are divided into two classes based on differences in the structure of the R2 side chain, this includes non-nitrogen-containing BPs (non-N-BPs), including etidronate and clodronate, and nitrogen-containing BPs (N-BPs), including alendronate, risedronate and pamidronate (3). Non-N-BPs are less potent antiresorptive agents compared with N-BPs; however, they exhibit other properties, including anticancer activities (4). These anticancer activities include inhibition of proliferation, induction of apoptosis, reduction of migration and invasion, and inhibition of angiogenesis $(1,5)$. BPs have demonstrated in vitro anticancer activity against various cancer cell lines, including breast (6), prostate (7), lung (8), endometrium (9) and colon cancer (10). However, further studies are required to investigate the specificity of different BPs for various cancer cell types and to elucidate the precise mechanisms of the anticancer activity.

It is important to investigate direct anticancer effects of BPs on cancer cell death, apoptosis and migration. In the past decade, BPs have been identified to be potent inhibitors of important enzymes in the mevalonate pathway, including farnesyl pyrophosphate synthase (FPPS) (11). FPPS is a key enzyme that catalyzes the reaction of isopentenyl pyrophosphate (IPP) and dimethylallyl pyrophosphate to generate farnesyl pyrophosphate (FPP) (5). This results in an increase in geranylgeranyl pyrophosphate (GGPP), which plays an important role in the production of small GTPases, including Ras, Rac, Rho and cell division control protein 42 homolog (CDC42) (11), and can subsequently control cancer cell proliferation. BPs strongly inhibit FPPS, which reduces the levels of FPP and GGPP and expression of small GTPases (5). Furthermore, BPs cause an accumulation of IPP that is converted to the cytotoxic adenosine 5'-triphoshpate analogue ApppI, which induces cancer cell death (12).

It has been suggested that BPs stimulate cancer cell death and apoptosis by inhibiting the mevalonate pathway and reducing the number of small GTPases $(13,14)$. This inhibits integrin-mediated cancer cell adhesion to the bone (15), increase Rap1 unprenylation, reduce the growth of mesothelioma cells (16) and deactivate Rho protein, which leads to inhibition of cancer cell migration (17). Small GTPases affect 
cancer cell cycle progression and/or growth by modulating the transcription of certain genes, including cyclin D, which stimulates the G1 to $\mathrm{S}$ transition and cancer cell proliferation $(18,19)$. The transcription of cyclin D1 is controlled by a number of transcription factors, including activator protein-1 and nuclear factor- $\kappa \mathrm{B}$, the activity of which are regulated by small GTPases $(18,19)$. Accordingly, direct inhibition of small GTPase activity induces cell cycle arrest and apoptosis in cancer cells by leading to decreased cell function and eventually programmed cell death (20). Zoledronic acid exhibits pronounced antiproliferative and proapoptotic effects in breast cancer MDA-MB-231 cells by increasing tumor necrosis factor-related apoptosis-inducing ligand (TRAIL) production and enhancing the TRAIL/osteoprotegerin (OPG) ratio, which affects cell integrity and survival (21).

The present study investigated the anticancer properties of three second-generation BPs, alendronate, risedronate and pamidronate, in MCF-7 human breast cancer cells using sulforhodamine B (SRB), colony formation and flow cytometry assays. The mechanism of BP-induced apoptosis was also explored by analyzing expression levels of apoptosis-associated proteins, reactive oxygen species (ROS) production, caspase-3 activity and mitochondrial function. Finally, effects of BPs on cancer cell migration were determined using a wound healing assay, gelatin zymography and by analyzing expression levels of genes associated with migration. The current study provides a valuable overview of the cytotoxic, apoptotic and antimigratory effects of different BPs on MCF-7 breast cancer cells.

\section{Materials and methods}

Chemicals and reagents. Alendronate, risedronate, pamidronate, protease inhibitor cocktail, dihydroethidium (DHE), radioimmunoprecipitation assay (RIPA) lysis buffer, Caspase-3 Fluorometric assay kit, GGPP, doxorubicin and SRB were obtained from Sigma-Aldrich; Merck KGaA (Darmstadt, Germany). Primary antibodies against cyclin D1 (cat. no. 2992), p21 (cat. no. 2947), cytochrome c (cat. no. 4272), caspase-3 (cat. no. 9662) and the internal control $\beta$-actin (cat. no. 4967), and the anti-rabbit IgG horseradish peroxidase (HRP)-conjugated antibody (cat. no. 7074) were purchased from Cell Signaling Technology, Inc. (Danvers, MA, USA). All cell culture reagents were purchased from Gibco; Thermo Fisher Scientific, Inc. (Waltham, MA, USA).

Cell lines, culture condition. The human breast cancer cell line MCF-7 was obtained from the American Type Culture Collection (Manassas, VA, USA) and maintained according to the manufacturer's protocol. The MCF-7 cell line was cultured in complete Dulbecco's modified Eagle's medium (DMEM) consisting of $10 \%$ fetal bovine serum, $100 \mathrm{U} / \mathrm{ml}$ penicillin $\mathrm{G}$ and $100 \mathrm{mg} / \mathrm{ml}$ streptomycin, and maintained under an atmosphere of $5 \% \mathrm{CO}_{2}$ at $37^{\circ} \mathrm{C}$. The cells were subcultured every 3 days or after cells reached $70-80 \%$ confluence using $0.25 \%$ trypsin-EDTA. Cells were plated in new complete DMEM until required for future experiments.

Cell viability assay. A SRB assay was used to measure the effect of the BPs alendronate, risedronate and pamidronate on the viability of MCF-7 cells. The assay was performed as previously described (22). In brief, MCF-7 cells were seeded into 96-well culture plates at $1 \times 10^{4}$ cells/well and allowed to attach for $24 \mathrm{~h}$. Subsequently, cultured cells were treated with various concentrations of BPs (0-1,000 $\mu \mathrm{M}$ alendronate and risedronate, $0-250 \mu \mathrm{M}$ pamidronate) for 24 and $48 \mathrm{~h}$ at $37^{\circ} \mathrm{C}$. Cells were then washed, fixed with $10 \%$ ice-cold trichloroacetic acid for $30 \mathrm{~min}$ at $4^{\circ} \mathrm{C}$, stained with $0.4 \% \mathrm{SRB}$ for $30 \mathrm{~min}$ at room temperature, washed with $1 \%$ acetic acid to remove unbound dye and the remaining protein-bound dye was then solubilized with $10 \mathrm{mM}$ unbuffered Tris. The absorbance was measured at $540 \mathrm{~nm}$ using a microplate reader. Cell viability was expressed in terms of percentage of untreated control absorbance following subtraction of mean background absorbance. $\mathrm{The}_{\mathrm{IC}} \mathrm{C}_{50}$ concentrations were calculated from the dose-response curves. Assays were performed in triplicate.

The effects of GGPP and doxorubicin with or without BPs on the MCF-7 cell line were also determined by SRB assay. This involved seeding MCF-7 cells into 96-well culture plates at $1 \times 10^{4}$ cells/well, allowing cells to attach for $24 \mathrm{~h}$ and then treating the cells with $5 \mu \mathrm{M}$ GGPP or $1 \mu \mathrm{M}$ doxorubicin with BPs $(250 \mu \mathrm{M}$ alendronate and risedronate, and $100 \mu \mathrm{M}$ pamidronate) or without BPs [0.25\% dimethyl sulfoxide (DMSO)] at $37^{\circ} \mathrm{C}$ for $24 \mathrm{~h}$. Cell viability was measured using the aforementioned protocol for SRB assay.

Clonogenic assay. The clonogenic assay was performed as previously described (22). MCF-7 cell lines were seeded into six-well culture plates at 500 cells/well for $24 \mathrm{~h}$ and following cell attachment fresh DMEM was added with BPs $(100 \mu \mathrm{M}$ alendronate and risedronate, and $50 \mu \mathrm{M}$ pamidronate) or without BPs $\left(0.25 \%\right.$ DMSO) at $37^{\circ} \mathrm{C}$ for $24 \mathrm{~h}$. The medium containing the BPs was subsequently removed from the culture plates, cells were washed with PBS, fresh DMEM was added and medium was renewed every 2 days. Following 2 weeks of treatment, the cell culture medium was removed for analysis and cells were washed with PBS. Cells were fixed in $100 \%$ methanol for $30 \mathrm{~min}$ at $-20^{\circ} \mathrm{C}$. Colonies were stained at room temperature for $1 \mathrm{~h}$ with $0.5 \%$ crystal violet in $25 \%$ (v/v) methanol and excess dye was removed by washing several times with water. Following washing and drying, the colonies were captured using a Nikon camera and counted to contain $>50$ cells/colony. Colony formation was expressed as a percentage relative to untreated cells. The clonogenic assay was performed in triplicate.

Wound healing assay. A wound healing assay was performed as previously described (22). MCF-7 cells were seeded into 24 -well culture plates at $2.5 \times 10^{5}$ cells/well and allowed to attach for $24 \mathrm{~h}$. Subsequently, monolayers of confluent cultures were scratched with a $0.2 \mathrm{ml}$ pipette tip, cell debris was washed away with PBS, cells were treated with BPs (0-50 $\mu \mathrm{M}$ alendronate, 0-100 $\mu \mathrm{M}$ risedronate, $0-25 \mu \mathrm{M}$ pamidronate) and without BPs $(0.25 \%$ DMSO) and images of the scratched wound were obtained at 0 and $72 \mathrm{~h}$ using phase contrast microscopy (magnification, $\mathrm{x} 40$ ). The wound distance was determined as the width of the scratch and treated and untreated groups were compared. The wound healing assay was performed in triplicate.

ROS formation assay. A ROS formation assay was performed by oxidation of DHE to the ethidium cation, which binds 
to intracellular ROS, as previously described (22). Briefly, MCF-7 cells were seeded into white 96-well culture plates at $1 \times 10^{4}$ cells/well and allowed to attach for $24 \mathrm{~h}$. Subsequently, cells were incubated with BPs $(0-1,000 \mu \mathrm{M}$ alendronate and risedronate, and $0-250 \mu \mathrm{M}$ pamidronate) or without BPs $(0.25 \% \mathrm{DMSO})$ and $25 \mu \mathrm{M} \mathrm{DHE}$ at $37^{\circ} \mathrm{C}$ for $90 \mathrm{~min}$ in a $5 \% \mathrm{CO}_{2}$ incubator in the dark. ROS production was assessed by measuring the fluorescence intensity with $518 \mathrm{~nm}$ excitation and $605 \mathrm{~nm}$ emission wavelengths. Data are expressed as the percentage of ROS relative to the control groups. The ROS formation assay was performed in triplicate.

Caspase-3 activity assay. Caspase-3 activity was measured using a caspase- 3 fluorometric assay kit, according to the manufacturer's instructions. Briefly, MCF-7 cells were seeded into 6 -well culture plates at $2.5 \times 10^{5}$ cells/well and allowed to attach for $24 \mathrm{~h}$. Cells were treated with BPs $(0-250 \mu \mathrm{M}$ alendronate and pamidronate, and $0-1,000 \mu \mathrm{M}$ risedronate) or without BPs (0.25\% DMSO) for $24 \mathrm{~h}$, cells were then lysed with lysis buffer and the protein concentration was measured using Bradford reagent. Caspase-3 activity reactions comprised of cell lysates and buffer containing the caspase- 3 substrate Ac-DEVD-AMC with the final volume being $\sim 200 \mu 1$. The reaction mixture was incubated at $37^{\circ} \mathrm{C}$ in the dark for $90 \mathrm{~min}$ and the fluorescence intensity was measured with $360 \mathrm{~nm}$ excitation and $460 \mathrm{~nm}$ emission wavelengths. Caspase-3 activity was calculated using fluorescent 7-amino-4-methylcoumarin (AMC) as a standard. The caspase-3 activity assay was performed in triplicate.

Mitochondrial transmembrane potential assay. To measure alterations in the mitochondrial transmembrane potential, the fluorescent dye JC-1 (JC-1 mitochondrial membrane potential assay kit; cat no. 10009172; Cayman Chemical Company, Ann Arbor MI, USA) was used. In brief, MCF-7 cells were seeded into black 96 -well culture plates at $1 \times 10^{4}$ cells/well and allowed to attach for $24 \mathrm{~h}$. Cells were then treated with BPs (0-1,000 $\mu \mathrm{M}$ alendronate and risedronate, and 0-250 $\mu \mathrm{M}$ pamidronate) or without BPs (0.25\% DMSO) for $24 \mathrm{~h}$ and cells were incubated with JC-1 dye for $30 \mathrm{~min}$ at $37^{\circ} \mathrm{C}$ in the dark. Subsequently, cells were rinsed and incubated in $200 \mu \mathrm{l}$ JC-1 assay buffer. Fluorescence intensity was measured with $485 \mathrm{~nm}$ excitation and $535 \mathrm{~nm}$ emission wavelengths. Assays were performed in triplicate.

Acridine orangelethidium bromide (AO/EB) staining. The $\mathrm{AO} / \mathrm{EB}$ assay was performed as previously described (22). Briefly, MCF-7 cells were seeded into 96-well culture plates at $1 \times 10^{4}$ cells/well and allowed to attach for $24 \mathrm{~h}$. Subsequently, cells were incubated with or without BPs $(0-1,000 \mu \mathrm{M}$ alendronate and risedronate, and $0-250 \mu \mathrm{M}$ pamidronate) or without BPs (0.25\% DMSO) for an additional $24 \mathrm{~h}$. Cells were then washed with PBS and stained with $1 \mu \mathrm{g} / \mathrm{ml} \mathrm{AO}$ and EB in PBS for 10-15 min at room temperature in the dark. Images were obtained using an inverted fluorescent microscope with excitation and long-pass emission filters of 480 and $535 \mathrm{~nm}$ (magnification, x200). Subsequently, images were examined and the number of viable, apoptotic and necrotic cells in the same area were counted. Data are expressed as percentage values relative to the control. Assays were performed in triplicate.
Cell apoptosis by flow cytometry. MCF-7 cell apoptosis was measured by flow cytometry. MCF-7 cells were seeded in six-well culture plates at $2.5 \times 10^{5}$ cells/well and allowed to attach for $24 \mathrm{~h}$. Cells were then exposed to BPs $(0-250 \mu \mathrm{M}$ alendronate and risedronate, and 0-50 $\mu \mathrm{M}$ pamidronate) or without BPs ( $0.25 \%$ DMSO) for $24 \mathrm{~h}$ prior to collection by trypsinization and washing with cold PBS. Cells were resuspended in $200 \mu \mathrm{l}$ binding buffer. Annexin V-fluorescein isothiocyanate (FITC) and propidium iodide (PI) staining was performed according to the manufacturer's protocol (FITC Annexin V apoptosis detection kit I; cat. no. 556547; BD Biosciences, San Jose, CA, USA). In brief, $5 \mu \mathrm{l}$ Annexin V-FITC $(1 \mathrm{mg} / \mathrm{ml})$ and $5 \mu 1$ PI $(2.5 \mathrm{mg} / \mathrm{ml})$ were added to $100 \mu \mathrm{l}$ of suspended cells and incubated at room temperature in the dark for 15 min prior to the addition of $400 \mu \mathrm{l}$ assay buffer. Data are expressed as the percentage of cells in each quadrant, which represent different stages of apoptosis following BPs treatment. Analysis was performed using BD Accuri C6 software (BD Biosciences). Assays were performed in triplicate.

Cell cycle analysis by flow cytometry. The cell cycle phase of MCF-7 cells was determined by flow cytometry. MCF-7 cells were seeded in 6 -well culture plates at $2.5 \times 10^{5}$ cells/well and allowed to attach for $24 \mathrm{~h}$. Cells were then exposed to BPs ( $250 \mu \mathrm{M}$ alendronate and risedronate, and $100 \mu \mathrm{M}$ pamidronate) or without BPs $(0.25 \%$ DMSO) for $24 \mathrm{~h}$ prior to collection and overnight fixation with $70 \%$ cold ethanol at $-20^{\circ} \mathrm{C}$. Following washing three times with PBS, cells were resuspended in $200 \mu$ l Guava Cell Cycle Reagent (cat. no. 4500-0220; Guava Technologies, Hayward, CA, USA) at room temperature in the dark for $30 \mathrm{~min}$. The DNA content of the cells was analyzed using a flow cytometer and the percentage of cells in different phases of the cell cycle was calculated using the Guava EasyCyte system with Cytosoft software v2.0 (Guava Technologies). Assays were performed in triplicate.

Matrix metallopeptidase (MMP)-9 expression by gelatin zymography. The effects of BPs on MMP-9 protein levels were assessed by gelatin zymography analysis. In brief, MCF-7 cells were seeded in 24 -well culture plates at $2.5 \times 10^{5}$ cells/well and allowed to attach for $24 \mathrm{~h}$. DMEM containing various concentrations of BPs $(250 \mu \mathrm{M}$ alendronate and risedronate, and $100 \mu \mathrm{M}$ pamidronate) or without BPs $(0.25 \%$ DMSO) was then added for $24 \mathrm{~h}$ at $37^{\circ} \mathrm{C}$. Subsequently, the medium was collected and concentrated by centrifugation at $12,000 \mathrm{x}$ g for $5 \mathrm{~min}$ using centrifugal filter units. The protein concentration was subsequently measured using Bradford's reagent. The proteins were mixed with $2 \mathrm{X}$ loading sample buffer $[1.5 \mathrm{ml} 0.5 \mathrm{M}$ Tris-HCl (pH 6.8), $2.5 \mathrm{ml}$ glycerol, $4 \mathrm{ml} \mathrm{10 \%}$ (w/v) SDS, $0.1 \mathrm{ml}$ $1 \%$ bromophenol blue and $2.15 \mathrm{ml}$ deionized water] for $20 \mathrm{~min}$ at room temperature in the dark. The $20 \mu \mathrm{g}$ protein samples were loaded onto $10 \%$ SDS-PAGE gel containing $0.01 \%(\mathrm{w} / \mathrm{v})$ gelatin and subjected to electrophoresis at $120 \mathrm{~V}$ for $90 \mathrm{~min}$. The gel was then washed three times with $2.5 \%$ Triton $\mathrm{X}-100$ and incubated with developing buffer [50 mM Tris-HCl buffer (pH 7.45) and $10 \mathrm{mM} \mathrm{CaCl}_{2}$ ] overnight at $37^{\circ} \mathrm{C}$. Subsequently, the gels were stained with $0.5 \%$ Coomassie Brilliant Blue $\mathrm{R}-250$ for $1 \mathrm{~h}$ at room temperature with shaking and gels were washed with destaining buffer [methanol $(25 \mathrm{ml})$, acetic acid (37.5 ml) and deionized water $(437.5 \mathrm{~mm})]$ until clear bands 
were observed against an intensely stained background. The band intensity was calculated using ChemiDoc ${ }^{\mathrm{TM}}$ Touch Imaging System (Bio-Rad Laboratories, Inc., Hercules, CA, USA). Assays were performed in triplicate.

Gene expression by reverse transcription-quantitative polymerase chain reaction $(R T-q P C R)$. RT-qPCR was used to determine the effect of BPs on Ras-related C3 botulinum toxin substrate 1 (Rac1), Ras homolog gene family member A (RhoA), cell division control protein 42 homolog (CDC42), MMP-2, MMP-9, intracellular adhesion molecule 1 (ICAM1) and vascular endothelial growth factor A (VEGFA) gene expression. In brief, MCF-7 cells were seeded in six-well culture plates at $2.5 \times 10^{5}$ cells/well and allowed to attach for $24 \mathrm{~h}$ at $37^{\circ} \mathrm{C}$. MCF-7 cells were then treated with BPs $(250 \mu \mathrm{M}$ alendronate and risedronate, and $100 \mu \mathrm{M}$ pamidronate) or without BPs $(0.25 \% \mathrm{DMSO})$ at $37^{\circ} \mathrm{C}$ for $24 \mathrm{~h}$ prior to the addition of $0.5 \mathrm{ml}$ TRIzol ${ }^{\circledR}$ reagent (cat. no. T9424; Sigma-Aldrich; Merck KGaA). Subsequently, RNA was isolated and complementary DNA was prepared using the iScript ${ }^{\mathrm{TM}}$ cDNA synthesis kit (cat. no. 1708898; Bio-Rad Laboratories, Inc.) at $42^{\circ} \mathrm{C}$ for $60 \mathrm{~min}$. PCR amplification was performed using primers for the target genes with $\beta$-actin used as an internal control. PCR primer sequences are presented in Table I and final reaction volume of $20 \mu \mathrm{l}$ was prepared containing SsoFast ${ }^{\mathrm{TM}}$ EvaGreen Supermix with low Rox (Bio-Rad Laboratories, Inc.), and primers for the target gene and the internal control $\beta$-actin. The PCR conditions were as follows: Denaturation at $95^{\circ} \mathrm{C}$ for $3 \mathrm{~min}$ and amplification by cycling 40 times at $95^{\circ} \mathrm{C}$ for $15 \mathrm{sec}$ and $60^{\circ} \mathrm{C}$ for $30 \mathrm{sec}$. Expression was detected using a CFX96 Touch $^{\mathrm{TM}}$ real-time PCR detection system (Bio-Rad Laboratories, Inc.). Differences in gene expression levels were calculated using the $2^{-\Delta \Delta \mathrm{Cq}}$ method (23) for relative quantification and expressed as the fold change relative to the untreated control. Assays assessing target gene expression were performed in triplicate.

Protein extraction and western blot analysis. Protein expression was assessed as described previously (22). In brief, MCF-7 cells were seeded in $75 \mathrm{~mm}$ flasks, allowed to attach for $24 \mathrm{~h}$ at $37^{\circ} \mathrm{C}$ and then treated with BPs $(250 \mu \mathrm{M}$ alendronate and risedronate, and $100 \mu \mathrm{M}$ pamidronate) or without BPs (0.25\% DMSO) at $37^{\circ} \mathrm{C}$ for $24 \mathrm{~h}$. Subsequently, pellets were collected and lysed with RIPA lysis buffer to extract the total protein, which was quantified using Bradford's reagent. Equal samples of $20 \mu \mathrm{g}$ protein were separated using 12\% SDS-PAGE gels and transferred to polyvinylidene difluoride membranes. The membranes were blocked in 5\% non-fat powdered milk/TBS/Tween-20 for $1 \mathrm{~h}$ at room temperature with shaking and incubated overnight at $4^{\circ} \mathrm{C}$ with the relevant primary antibodies against p21 $(1: 1,000)$, cyclin D1 $(1: 1,000)$, cytochrome c $(1: 1,000)$, caspase-3 $(1: 1,000)$ and $\beta$-actin $(1: 2,500)$. This was followed by a $2 \mathrm{~h}$ treatment with HRP-conjugated secondary antibody $(1: 5,000)$ at room temperature with shaking. Blots were washed and visualized using Clarity ${ }^{\mathrm{TM}}$ Western Enhanced Chemiluminescent Substrate (cat. no. 1705060; Bio-Rad Laboratories, Inc.) and calculated using ChemiDoc $^{\mathrm{TM}}$ Touch Imaging System (Bio-Rad, Laboratories, Inc.). Assays were performed in triplicate.

Statistical analysis. Control and treatment groups were statistically compared using Student's t-test or one-way analysis of variance followed by Tukey's post-hoc test using SigmaStat software version 3.5 (Systat Software Inc., San Jose, CA, USA) and values are expressed as the mean \pm standard error of the mean of three experiments. $\mathrm{P}<0.05$ was considered to indicate a statistically significant result.

\section{Results}

Effects of BPs on cell death and colony formation efficacy. The cytotoxic effect of the BPs alendronate, risedronate and pamidronate in MCF-7 human breast cancer cells and their ability to disrupt MCF-7 cell replication were assessed by SRB and colony formation assay. The results demonstrated that the BPs exerted a cytotoxic effect on MCF-7 cells in a concentration- and time-dependent manner, with $\mathrm{IC}_{50}$ values for alendronate, risedronate and pamidronate at $48 \mathrm{~h}$ calculated as $69.5 \pm 5.6,248.0 \pm 10.4$ and $22.9 \pm 1.5 \mu \mathrm{M}$, respectively (Fig. 1A-D). Accordingly, pamidronate exhibited greater cytotoxicity compared with alendronate and risedronate against human breast cancer cells.

The effects of BPs on the longer term viability and replicative ability of MCF-7 cells was determined using a colony formation assay. It was identified that cells treated with BPs underwent a concentration-dependent decrease in colony forming ability (Fig. 1E-H). A significant inhibitory effect was observed at doses $>10,>25$ and $50 \mu \mathrm{M}$ for alendronate, risedronate and pamidronate, respectively. The greatest inhibition of replicative ability was by risedronate followed by alendronate and pamidronate, with $\mathrm{IC}_{50}$ values of $15.2 \pm 1.2,46.9 \pm 2.5$ and $36.3 \pm 3.4 \mu \mathrm{M}$, respectively. In summary, these results indicate that BPs inhibit MCF-7 cell growth and induce MCF-7 cell death.

To determine if the effects of BPs on cell viability were inhibited by the mevalonate product GGPP, or if the BPs exerted any synergistic effects with the anticancer drug doxorubicin, their combined effects were examined using a SRB assay. The results demonstrated that pretreatment of MCF-7 cells with $5 \mu \mathrm{M}$ GGPP in the absence of BPs slightly stimulates their growth but not significantly. The addition of GGPP in the presence of the BPs risedronate and pamidronate significantly reversed the effects of the BPs on cell viability (Fig. 2A). To determine if doxorubicin was potentiated by the BPs, MCF-7 cell viability was assessed in the presence of the two types of drugs. By adding $250 \mu \mathrm{M}$ of alendronate, $250 \mu \mathrm{M}$ of risedronate, or $100 \mu \mathrm{M}$ of pamidronate to the culture medium containing $1 \mu \mathrm{M}$ doxorubicin, the antiproliferative effects of doxorubicin were improved in all treatment groups (Fig. 2B).

Effects of BPs on Racl, RhoA and CDC42 gene expression. Members of the Rho GTPase family, including RhoA, Rac1 and $\mathrm{CDC} 42$, are involved in regulating a variety of normal and cancer cellular processes (24), and Rho GTPase genes are dysregulated in numerous types of cancer cells (25). Results from the present study revealed that treatment of MCF-7 cells with BPs for $24 \mathrm{~h}$ resulted in altered expression levels of the Rac1, RhoA and CDC42 genes (Fig. 2C). Rac1 and RhoA levels were significantly upregulated in the alendronate and risedronate treatment groups, but significantly reduced in the pamidronate treatment group. Furthermore, all BPs significantly reduced CDC42 gene expression. In conclusion, the current results demonstrated that BPs may modulate 
Table I. Primer sequences for reverse transcription-quantitative polymerase chain reaction.

\begin{tabular}{lll}
\hline Gene & Forward primer sequence $\left(5^{\prime}-3^{\prime}\right)$ & Reverse primer sequence $\left(5^{\prime}-3^{\prime}\right)$ \\
\hline Rac1 & ATGTCCGTGCAAAGTGGTATC & CTCGGATCGCTTCGTCAAACA \\
RhoA & GGAAAGCAGGTAGAGTTGGCT & GGCTGTCGATGGAAAAACACAT \\
CDC42 & CCATCGGAATATGTACCGACTG & CTCAGCGGTCGTAATCTGTCA \\
MMP-2 & GATACCCCTTTGACGGTAAGGA & CCTTCTCCCAAGGTCCATAGC \\
MMP-9 & GGGACGCAGACATCGTCATC & TCGTCATCGTCGAAATGGGC \\
ICAM1 & GTATGAACTGAGCAATGTGCAAG & GTTCCACCCGTTCTGGAGTC \\
VEGFA & AGGGCAGAATCATCACGAAGT & AGGGTCTCGATTGGA-TGGCA \\
-actin & GTGACGTTGACATCCGTAAAGA & GCCGGACTCATCGTACTCC
\end{tabular}

Rac1, Ras-related C3 botulinum toxin substrate 1; RhoA, Ras homolog gene family member A; CDC42, cell division control protein 42 homolog; MMP, matrix metallopeptidase; ICAM1, intracellular adhesion molecule 1; VEGFA, vascular endothelial growth factor.

\section{A}

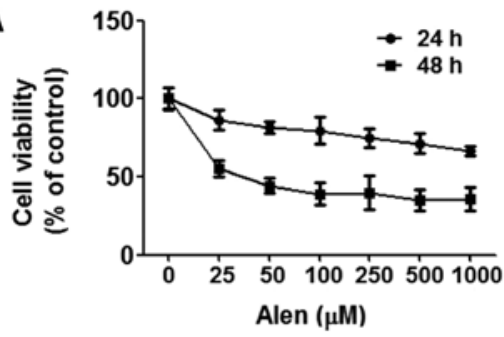

B

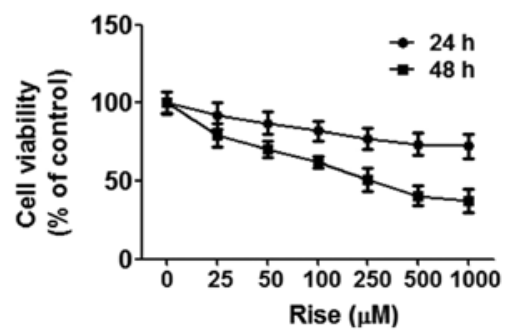

C

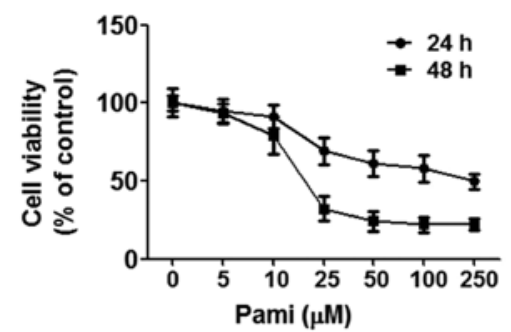

\begin{tabular}{|l|c|c|}
\hline Bisphosphonates & $\begin{array}{c}\text { Incubation times } \\
(\mathrm{h})\end{array}$ & $\mathrm{IC}_{50}(\mu \mathrm{M})$ \\
\hline \multirow{3}{*}{ Alen } & 24 & $1239.3 \pm 67.9$ \\
\hline \multirow{3}{*}{ Rise } & 48 & $69.5 \pm 5.6$ \\
\hline \multirow{3}{*}{ Pami } & 24 & $1599.0 \pm 157.5$ \\
\cline { 2 - 3 } & 48 & $248.0 \pm 10.4$ \\
\hline & 24 & $126.6 \pm 12.6$ \\
\cline { 2 - 3 } & 48 & $22.9 \pm 1.5$ \\
\hline
\end{tabular}

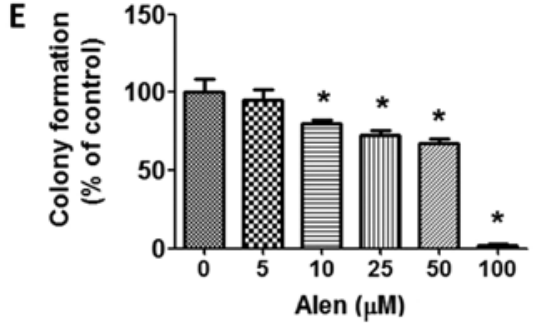

$\mathbf{F}$

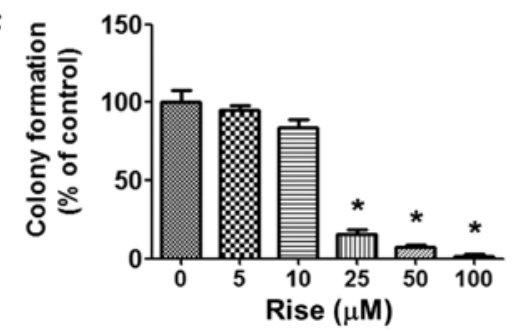

G

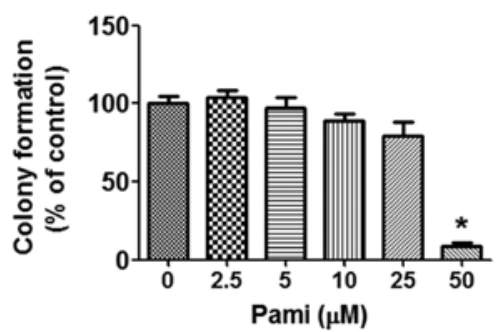

\begin{tabular}{|l|r|}
\cline { 2 - 2 } Bisphosphonates & $\mathrm{IC}_{50}(\mu \mathrm{M})$ \\
\hline Alen & $46.9 \pm 2.5$ \\
\hline Rise & $15.2 \pm 1.2$ \\
\hline Pami & $36.3 \pm 3.4$ \\
\hline
\end{tabular}

Figure 1. Effect of BPs on MCF-7 cell proliferation and growth. MCF-7 cells were treated with $(\mathrm{A})$ alendronate $(0-1,000 \mu \mathrm{M}),(\mathrm{B})$ risedronate $(0-1,000 \mu \mathrm{M})$ and $(\mathrm{C})$ pamidronate $(0-250 \mu \mathrm{M})$ for 24 and $48 \mathrm{~h}$ and cell proliferation was determined using a sulforhodamine $\mathrm{B}$ assay. (D) $\mathrm{IC}_{50}$ values determined for the BPs from the proliferation assay data. To investigate colony formation, MCF-7 cells were treated with $(\mathrm{E})$ alendronate $(0-100 \mu \mathrm{M})$, $(\mathrm{F})$ risedronate $(0-100 \mu \mathrm{M})$ and (G) pamidronate $(0-50 \mu \mathrm{M})$ for $24 \mathrm{~h}$ and following 14 days of culturing, cells were stained with crystal violet and the number of colonies was. $(\mathrm{H}) \mathrm{IC}_{50}$ values determined for the BPs from the colony formation assay data. The results are presented as a percentage of control and as the mean \pm standard error of the mean. ${ }^{*} \mathrm{P}<0.05$ vs. control group. Alen, alendronate; Rise, risedronate; Pami, pamidronate.

Rho GTPase gene expression in the mevalonate pathway. Therefore, it was suggested that BPs interrupted an important step of cholesterol synthesis, which may induce breast cancer cell death, however, additional studies are required. 

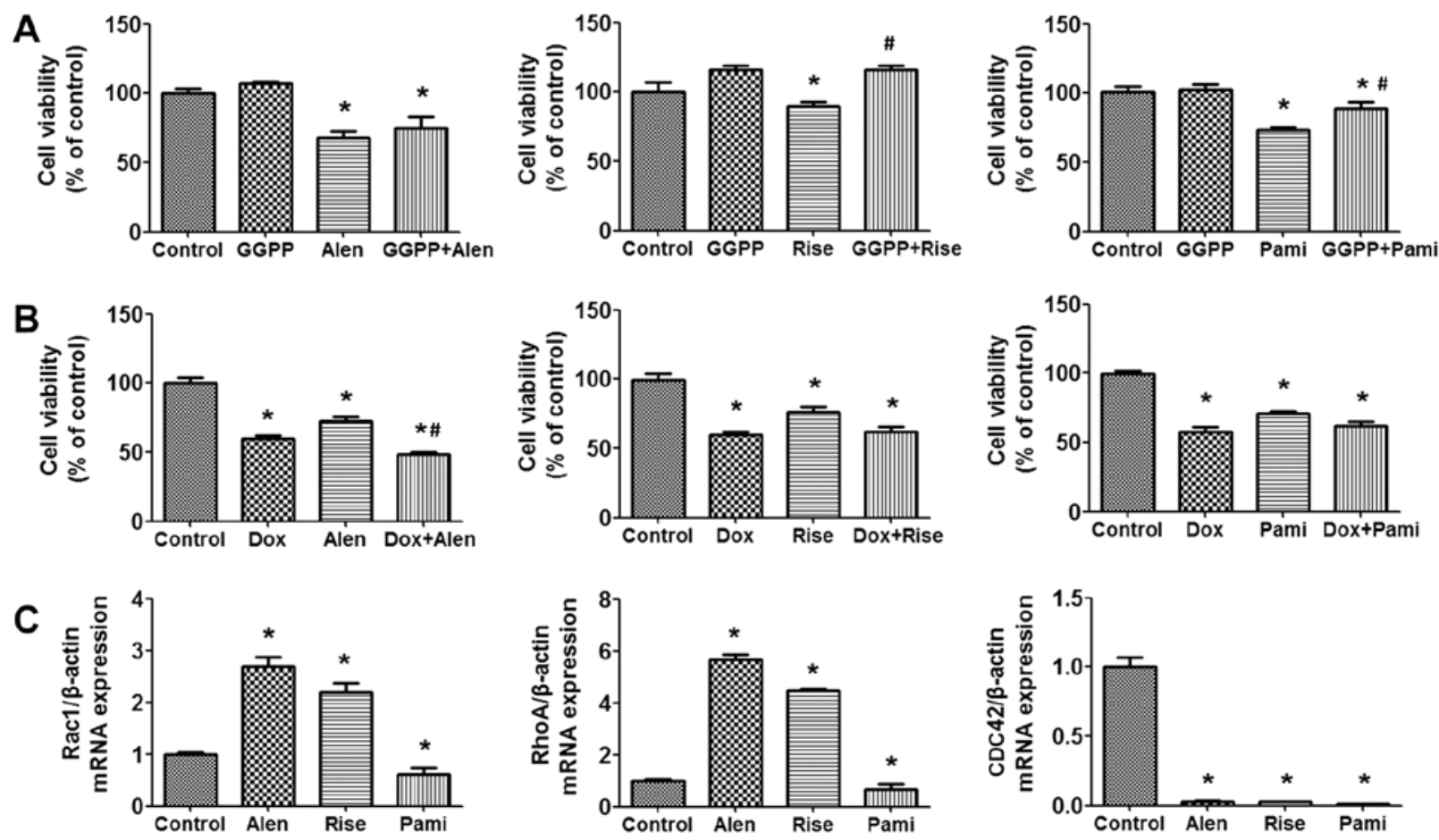

Figure 2. Effect of GGPP and doxorubicin in combination with BPs on cell viability and Rho GTPase gene expression. MCF-7 cells were treated with $250 \mu \mathrm{M}$ Alen, $250 \mu \mathrm{M}$ Rise and $100 \mu \mathrm{M}$ Pami with or without (A) $5 \mu \mathrm{M}$ GGPP or (B) $1 \mu \mathrm{M}$ Dox for 24 h and cell viability was measured by sulforhodamine B assay. (C) Cells were treated with $250 \mu \mathrm{M}$ Alen, $250 \mu \mathrm{M}$ Rise and $100 \mu \mathrm{M}$ Pami for $24 \mathrm{~h}$ and Rac1, RhoA and CDC42 mRNA expression levels were determined by reverse transcription-quantitative polymerase chain reaction. Data are presented as the mean \pm standard error of the mean. ${ }^{\mathrm{P}}<0.05$ vs. control group. "P<0.05 vs. BP-treated group. Alen, alendronate; Rise, risedronate; Pami, pamidronate; GGPP, geranylgeranyl pyrophosphate; Dox, doxorubicin; Rac, Ras-related C3 botulinum toxin substrate; Rho, Ras homolog gene family; CDC42, cell division control protein 42 homolog; BP, bisphosphonate.

Effects of BPs on MCF-7 cell cycle progression and expression of proteins associated with cell cycle. To investigate whether BP-induced inhibition of MCF-7 cell growth was mediated via the alteration of the cell cycle progression, flow cytometry was used to determine the cell cycle phase distribution in MCF-7 cells. The results demonstrated that BPs caused an increase in the percentage of cells in the G1 phase with significant effects occurring at doses of $250 \mu \mathrm{M}$ alendronate, $250 \mu \mathrm{M}$ risedronate and $100 \mu \mathrm{M}$ pamidronate (Fig. 3A). Furthermore, BPs reduced the percentage of cells in the $\mathrm{S}$ and $\mathrm{G} 2 / \mathrm{M}$ phases, which is consistent with G1 phase arrest. These data demonstrated that alendronate induced cell cycle arrest, particularly G1 phase arrest, in the MCF-7 cells to a greater extent compared with the other BPs.

To further investigate which molecules were affected by BPs, the expression levels of cell cycle-associated proteins were assessed by western blot analysis. The results demonstrated that treatment with $250 \mu \mathrm{M}$ alendronate, $250 \mu \mathrm{M}$ risedronate and $100 \mu \mathrm{M}$ pamidronate was associated with a significant decrease in the levels of cyclin D1 (Fig. 3B), with pamidronate inducing the greatest change. Furthermore, the BPs risedronate and pamidronate inhibited cancer cell proliferation by significantly inducing the cyclin Dependent kinase inhibitor p21 (Fig. 3B). In conclusion, the results indicated that BPs inhibited cell proliferation by inducing MCF-7 cell arrest in the G1 phase, inhibiting cell cycle protein cyclin D1 and inducing cell cycle inhibitor p21 protein.

Effect of BPs on ROS formation, caspase-3 activity and mitochondrial membrane potential. To investigate the mechanism by which BPs induced MCF-7 apoptotic cell death and
ROS formation, caspase- 3 activity and mitochondrial transmembrane potential were assessed. A significant increase in ROS formation was induced by all BPs at a concentration of $250 \mu \mathrm{M}$ (Fig. 4A). A high concentration of alendronate and risedronate $(1,000 \mu \mathrm{M})$ further induced a significant increase in ROS production compared with the control group. In addition, all BPs increased caspase- 3 activity in a dose-dependent manner, with significant inductive effects observed with $>50 \mu \mathrm{M}$ alendronate, $>50 \mu \mathrm{M}$ pamidronate and $1,000 \mu \mathrm{M}$ risedronate (Fig. 4B). It was also identified that BPs significantly decreased the mitochondrial transmembrane potential of MCF-7 cells compared with the control, with pamidronate exhibiting the most significant reduction in mitochondrial activity (Fig. 4C).

Effect of BPs on induction of apoptotic cell death. To determine the effect of BPs on the apoptotic cell death of MCF-7 cells, AO/EB staining, flow cytometry and western blot analysis were performed. To investigate the mode of cell killing by BPs, BP-treated MCF-7 cells were stained with the fluorescent dye $\mathrm{AO} / \mathrm{EB}$. The results revealed that cells underwent cell death, apoptosis and necrosis following incubation with the BPs for $24 \mathrm{~h}$. The number of viable cells decreased in a dose-dependent manner following treatment with BPs, with necrotic cells increasing in number. Notably, significant induction of apoptotic cell death was observed following treatment with $250 \mu \mathrm{M}$ alendronate, $250-1,000 \mu \mathrm{M}$ risedronate and 50-250 $\mu \mathrm{M}$ pamidronate (Fig. 5). Furthermore, high concentrations of the BPs also induced dose-dependent necrotic cell death following treatment with 500-1,000 $\mu \mathrm{M}$ alendronate, $1,000 \mu \mathrm{M}$ risedronate and $100-250 \mu \mathrm{M}$ pamidronate. These 

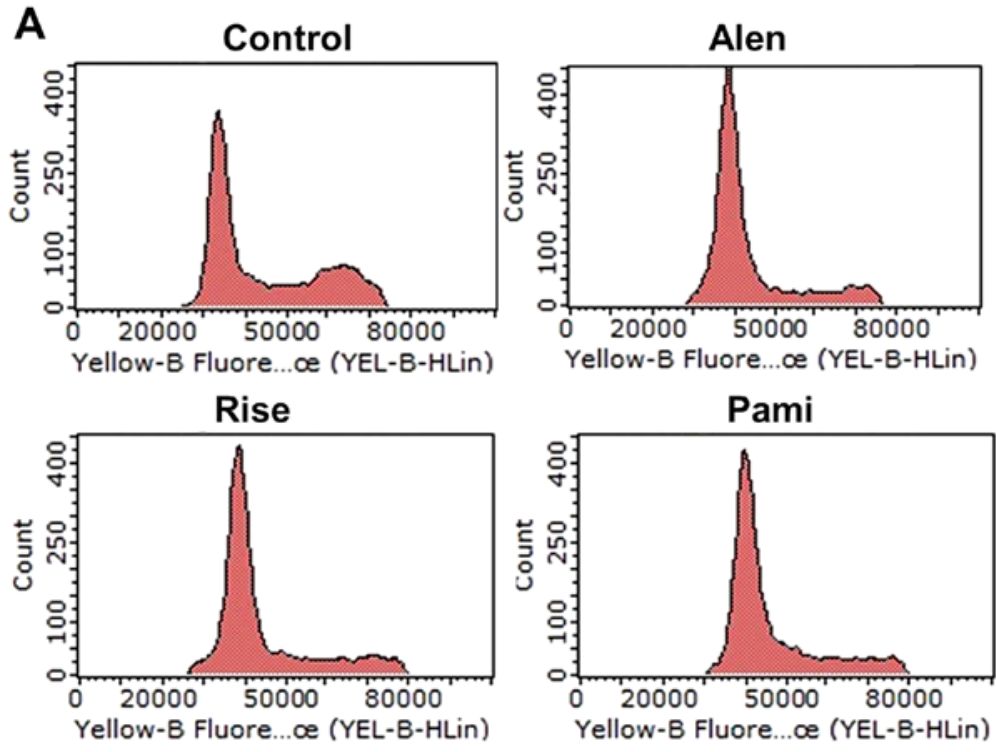

\begin{tabular}{|c|c|c|c|c|}
\hline $\begin{array}{c}\text { Cell } \\
\text { cycle }\end{array}$ & Control & Alen & Rise & Pami \\
\hline G1 & $53.4 \pm 1.6$ & $72.76 \pm 1.3^{\star}$ & $67.73 \pm 1.5^{\star}$ & $66.7 \pm 1.2^{\star}$ \\
\hline S & $23.1 \pm 2.7$ & $15.35+1.1^{\star}$ & $14.5 \pm 1.3^{\star}$ & $17.3 \pm 1.4^{\star}$ \\
\hline G2M & $23.59 \pm 4.2$ & $11.19 \pm 1.5^{\star}$ & $16.6 \pm 2.5^{\star}$ & $15.5 \pm 0.8^{\star}$ \\
\hline
\end{tabular}

B
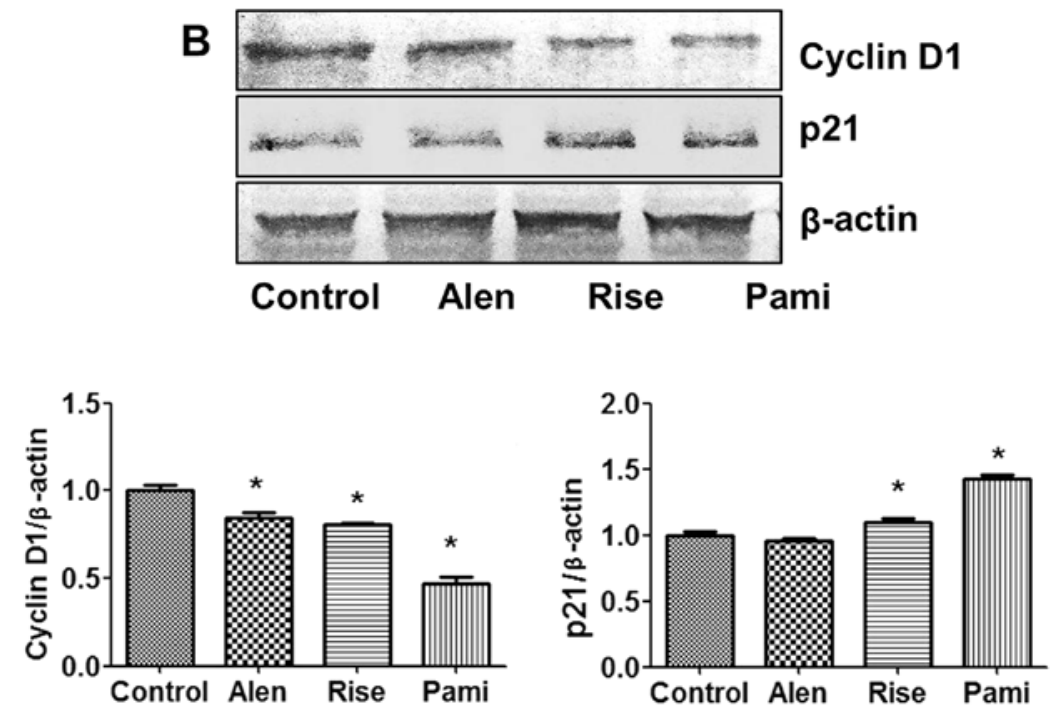

Figure 3. Effect of BPs on cell cycle- and apoptosis-associated proteins in MCF-7 cells. MCF-7 cells were treated with $250 \mu \mathrm{M}$ Alen, $250 \mu \mathrm{M}$ Rise and $100 \mu \mathrm{M}$ Pami for $24 \mathrm{~h}$. (A) Cell cycle analysis was performed using flow cytometry and representative histograms and a summary table indicating the percentage of cells in each phase are presented. (B) Western blot analysis was performed to assess expression levels of cyclin D1 and p21 normalized to $\beta$-actin. Data are presented as the mean \pm standard error of the mean. ${ }^{~} \mathrm{P}<0.05$ vs. control group. Alen, alendronate; Rise, risedronate; Pami, pamidronate; BP, bisphosphonate.

results indicate that BPs exhibit significant effects on breast cancer cell apoptosis and cell death.

To investigate whether apoptosis was involved in the action of BPs on MCF-7 cells, the proportion of apoptotic cells were determined using a flow cytometer by staining samples with PI and Annexin V-FITC. Significant BP-induced apoptosis of MCF-7 cells was identified, as demonstrated in Fig. 6A. Compared with the control group, the proportion of viable cells decreased and the proportion of early and late apoptotic cells significantly increased following $24 \mathrm{~h}$ incubation with the BPs.

To gain insight into the molecular mechanism by which BPs induced MCF-7 cell death, western blot analysis was performed. All BPs demonstrated a similar pattern of changes in the expression levels of apoptosis-associated proteins in MCF-7 cells. The BPs significantly increased cytochrome $\mathrm{c}$ and caspase-3 protein expression levels compared with the untreated control group (Fig. 6B).

Effect of BPs on cell migration. To determine the effect of BPs on MCF-7 cell migration, a wound healing assay, gelatin zymography and RT-qPCR were performed. BPs were identified to significantly inhibit MCF-7 cell migration in a dose-dependent manner (Fig. 7A). The inhibitory effects of risedronate and pamidronate on MCF-7 cell migration were 
A

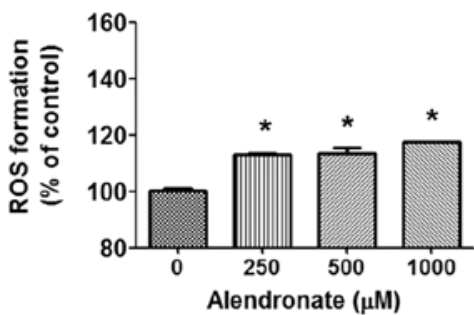

B

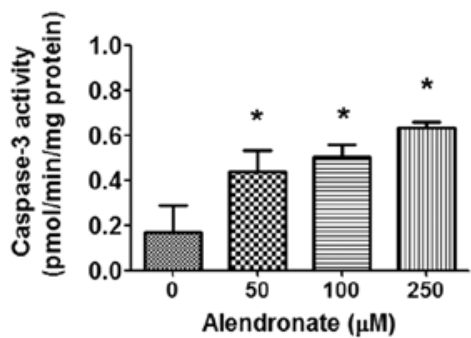

C

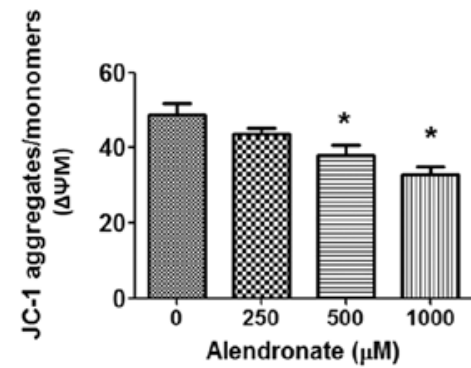

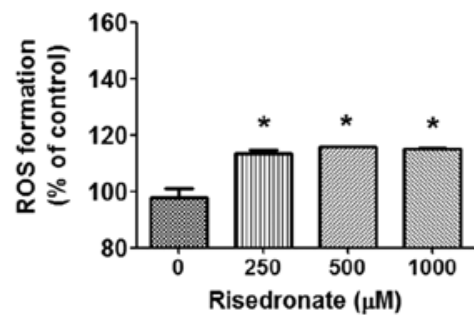
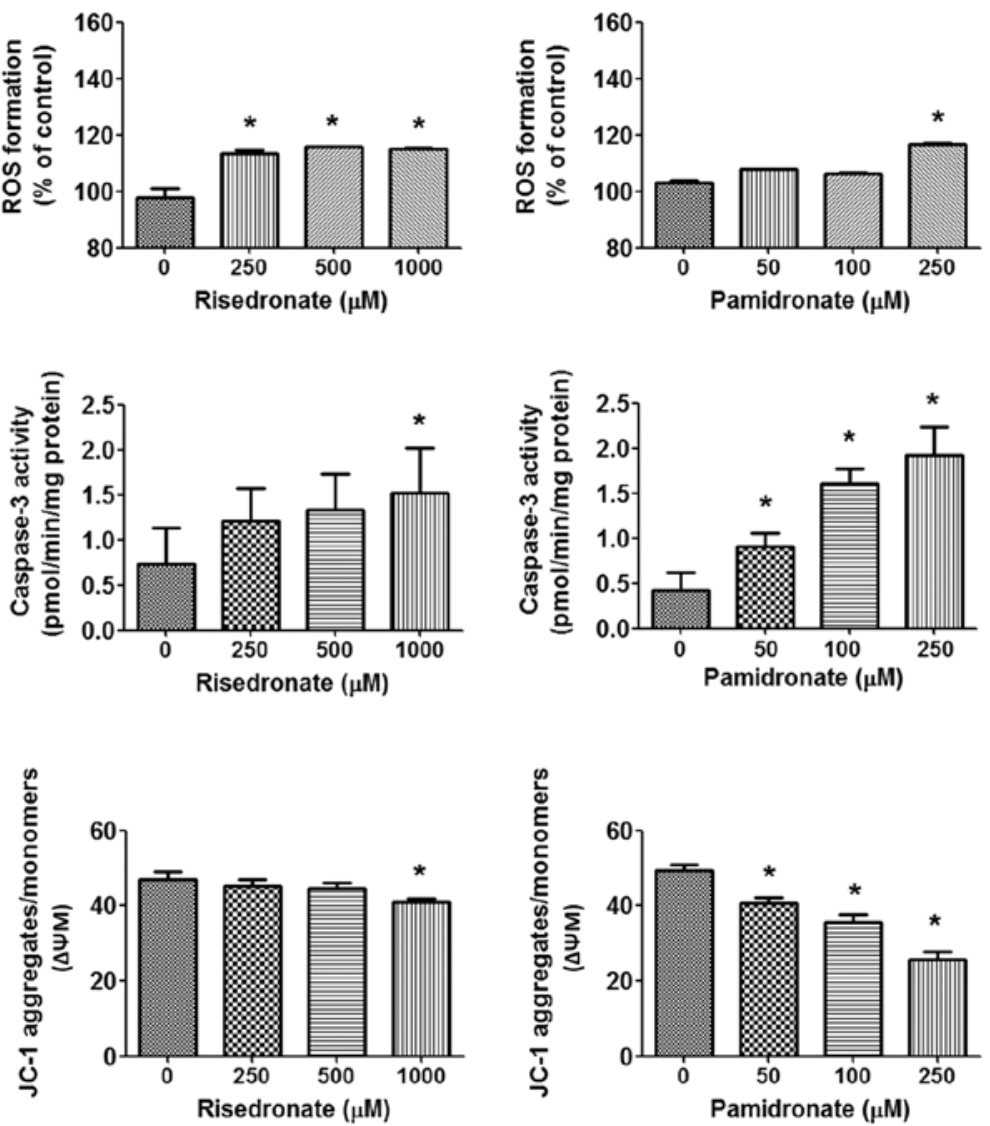

Figure 4. Effect of BPs on ROS formation, caspase-3 activity and mitochondrial transmembrane potential. (A) ROS formation was assessed in cells incubated with BPs at the varying concentrations and quantified by the dihydroethidium-enhanced fluorescence method following incubation ( 90 min). (B) Caspase-3 activity was determined in cells treated with various concentrations of BPs. (C) Mitochondrial function was investigated in cells treated with BPs and stained with JC-1 dye. Data are presented as the mean \pm standard error of the mean of three experiments. ${ }^{*} \mathrm{P}<0.05$ vs. control group. ROS, reactive oxygen species; BP, bisphosphonate.

revealed to be markedly higher compared with alendronate. Risedronate and pamidronate also significantly inhibited MMP-9 protein expression levels in the culture medium to a greater extent compared with alendronate (Fig. 7B). In addition, treatment with BPs was associated with increased MMP-2, MMP-9, VEGFA and ICAM1 gene expression levels compared with the untreated control groups (Fig. 7C).

\section{Discussion}

BPs influence cell proliferation and programmed cell death in different cancer cell lines, possibly by inhibiting the production of mevalonate products (3). However, not all BPs exhibit identical effects on breast cancer MCF-7 cells in vitro. The present study examined the BPs alendronate, risedronate and pamidronate for their capacity to inhibit MCF-7 breast cancer cell proliferation and suppress the metastatic potential of MCF-7 cells. It was identified that pamidronate exhibited the most potent effects. In addition, the mevalonate product GGPP was revealed to reverse BP-induced cancer cell death. When the BPs were combined with the anticancer drug doxorubicin, an enhanced antiproliferative effect was observed compared with doxorubicin alone. The BPs were also identified to modulate the expression of the Rho GTPase family genes Rac1, RhoA and CDC42. Regarding the mechanism underlying the aforementioned effects on MCF-7 cells, the BPs were revealed to inhibit cell proliferation by inducing cell cycle arrest in the G1 phase, which was associated with a downregulation of cyclin D1 and an upregulation of p21. The BPs induced MCF-7 cell death by increasing ROS formation, increasing caspase-3 activity and reducing mitochondrial function. Furthermore, an alternative mechanism of BP-induced cell death was revealed to be associated with an increase in cytochrome $\mathrm{c}$ and caspase-3 protein expression levels. Finally, the BPs inhibited cancer cell migration by reducing MMP-9 protein expression levels. Therefore, BPs may potentially be developed as drugs for the treatment or prevention of breast cancer, or for the potentiation of anticancer drugs that are currently in clinical use.

Results from the present study demonstrated that BPs reduce both cancer cell proliferation and cell growth. This was hypothesized to occur via interactions between BPs and cell cycle-associated proteins, which may lead to cell cycle arrest. Investigation of the effect of BPs on MCF-7 cells indicated that BPs induce cell death and inhibit cell growth in a dose-dependent manner. A previous study has demonstrated that BPs inhibit FFPS in the mevalonate pathway, causing a reduction of GGPP and FPP, and reducing the expression levels of Rho GTPase proteins, including Rac1, RhoA and CDC42 (26). Rho GTPases are important regulators of cell cycle progression and proliferation; they have been identified to be overexpressed in human tumors and their overexpression levels have been associated with cancer progression (27). The present study revealed that 

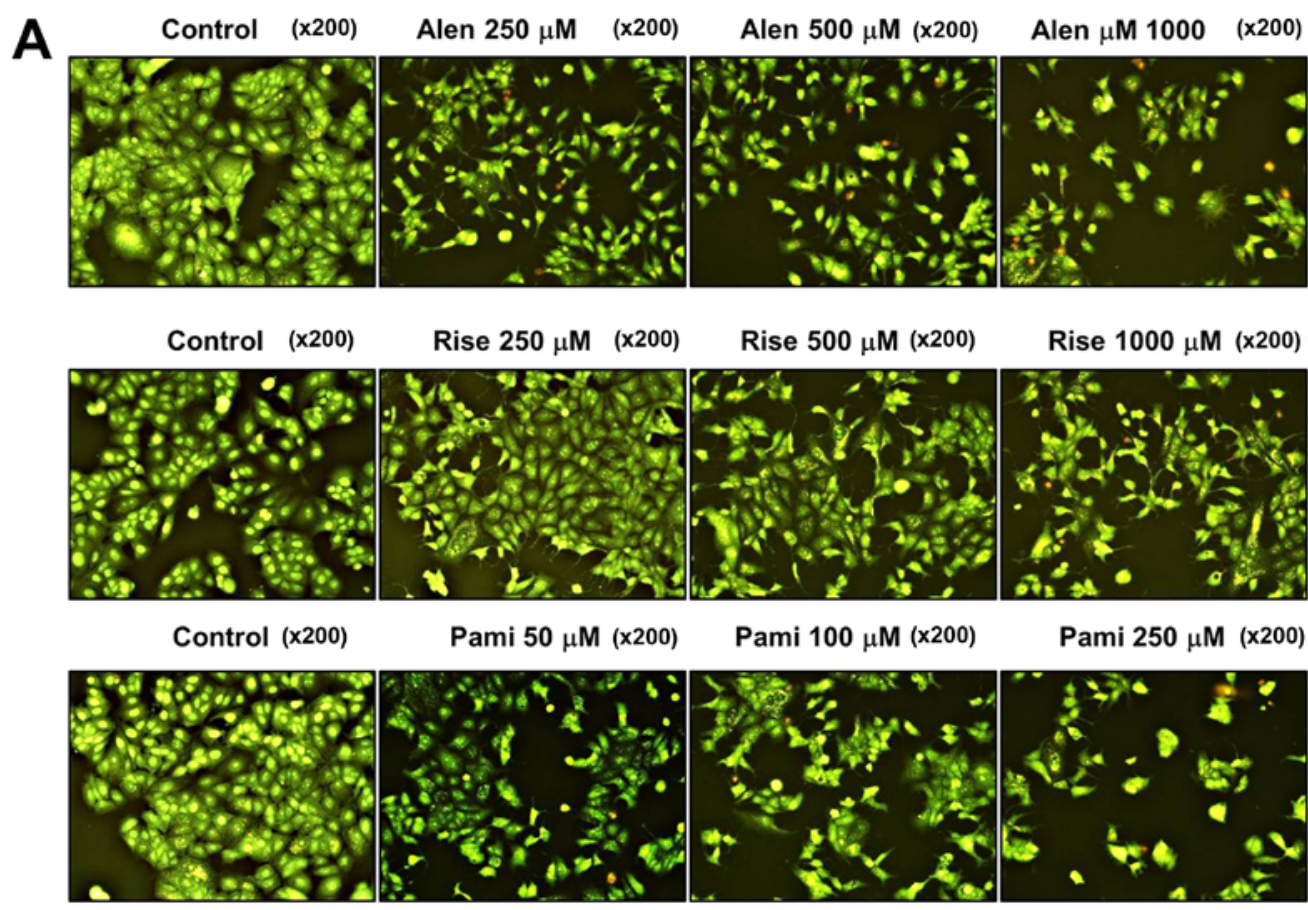

B
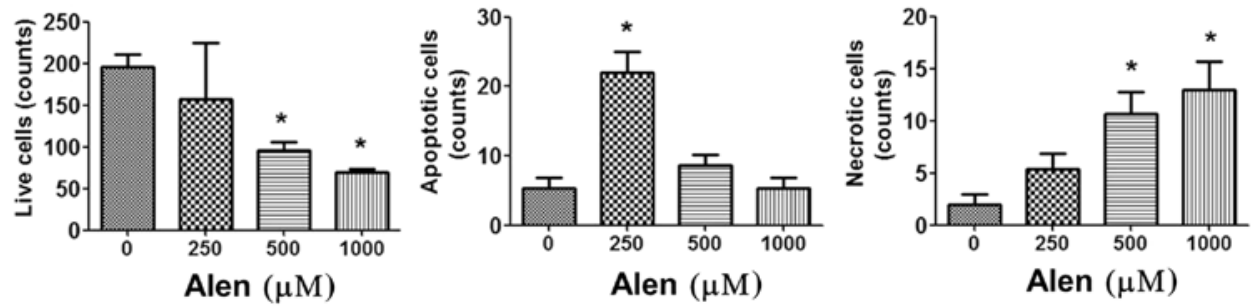

C
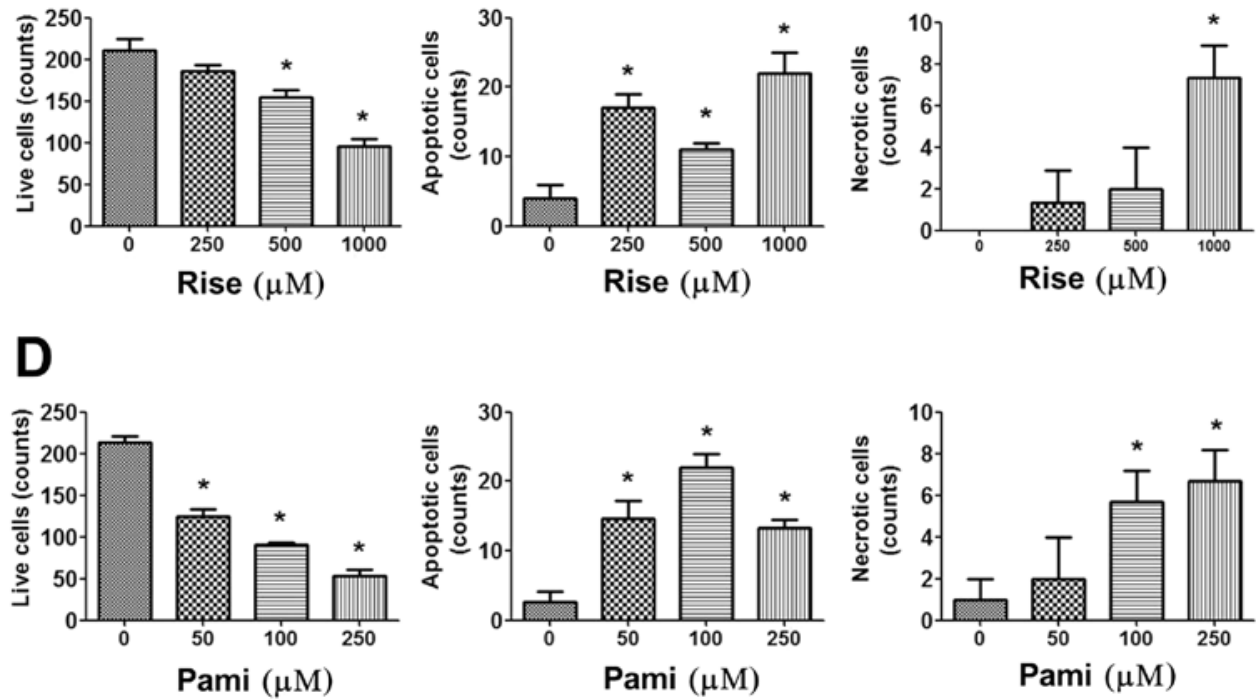

Figure 5. Effect of BPs on MCF-7 cell apoptosis. MCF-7 cells were treated with various concentrations of BPs for 24 h prior to staining with acridine orange/ethidium bromide. (A) Images obtained by fluorescence microscopy (magnification, x200). (B-D) The numbers of live, apoptotic, and necrotic cells after treatment with BPs. ${ }^{*}<0.05$ vs. control group. Alen, alendronate; Rise, risedronate; Pami, pamidronate; BP, bisphosphonate.

BP-induced cancer cell death was reversed by GGPP treatment. It was also identified that BPs potentiated the effect of anticancer drug doxorubicin and that BPs modulated Rho GTPase gene expression. Notably, pamidronate was demonstrated to be the most potent $\mathrm{BP}$, as pamidronate significantly reduced the expression levels of small GTPases Rac1, RhoA and CDC42. However, Racl and RhoA were significantly upregulated in the alendronate and risedronate treatment groups, which may explain why pamidronate exhibited the highest cytotoxic effects on MCF-7 cells. 

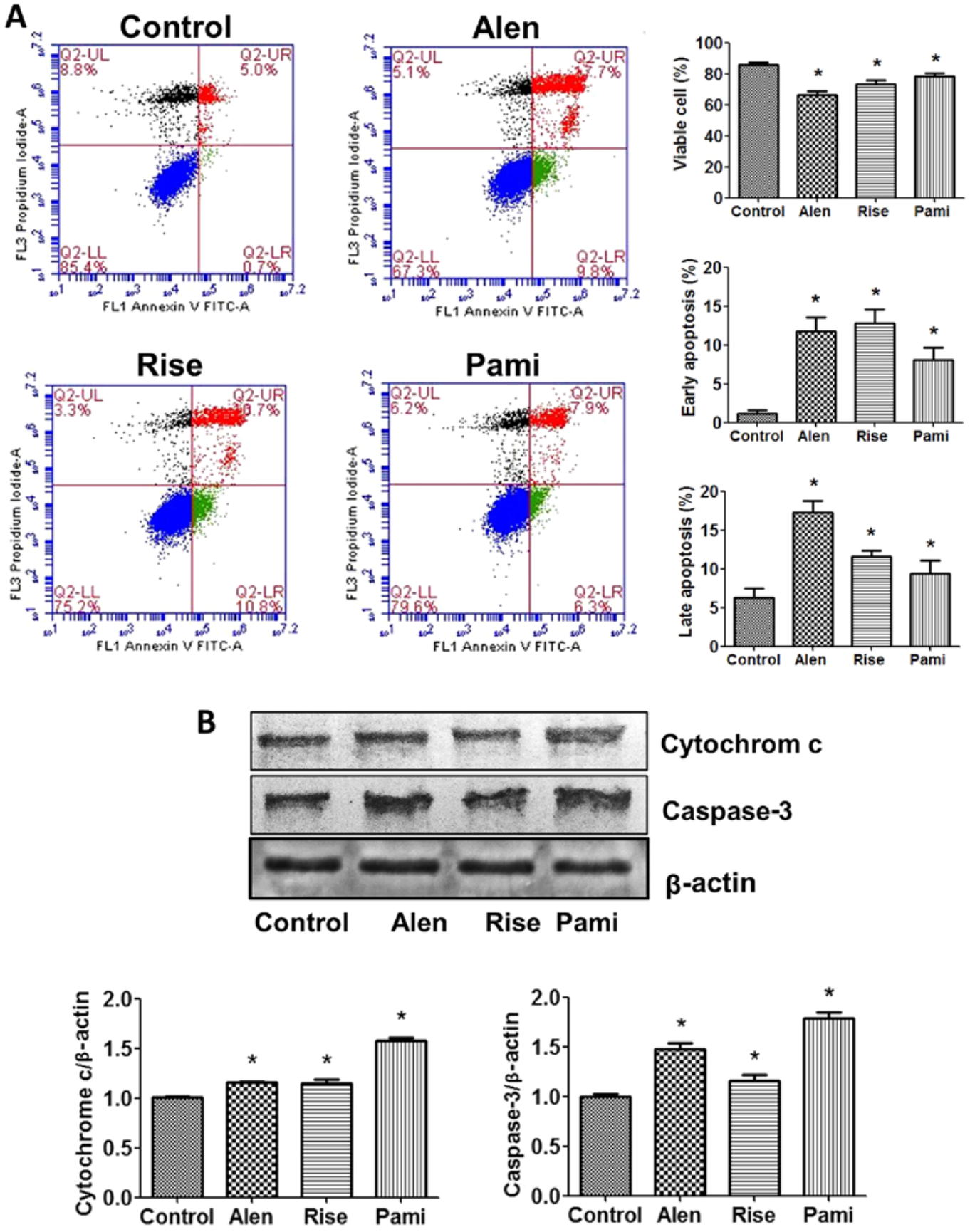

Figure 6. Effect of BPs on cell apoptosis and apoptosis-associated proteins in MCF-7 cells. MCF-7 cells were treated with $250 \mu \mathrm{M}$ alendronate, $250 \mu \mathrm{M}$ risedronate and $100 \mu \mathrm{M}$ pamidronate for $24 \mathrm{~h}$. (A) Apoptosis rates were determined by flow cytometry and representative graphs and the percentage viable, early and late apoptotic cells are presented for the different treatment groups. (B) Following treatment, whole cell extracts were subjected to western blot analysis and expression levels of cytochrome $c$ and caspase- 3 were determined and normalized to $\beta$-actin. Data are presented as the mean \pm standard error of the mean. ${ }^{*} \mathrm{P}<0.05$ vs. control group. Alen, alendronate; Rise, risedronate; Pami, pamidronate; FITC, fluorescein isothiocyanate; BP, bisphosphonate.

Furthermore, to determine the effects of BPs on the cell cycle and cell cycle-associated proteins, flow cytometry analysis and western blot analysis were performed. The results revealed that BPs significantly increased the percentage of cells in the G1 phase and decreased the percentage of cells in the S and G2 phases. Alendronate exhibited the most potent activity. The effect of BPs on MCF-7 cells was associated with inhibition of cyclin D1 expression, induction of p21 expression and cell cycle arrest. p21 is a cell cycle dependent kinase inhibitor that regulates the cell cycle (28). In addition, p21 serves an essential role in growth arrest following DNA damage and overexpression of p21 leads to G1 and G2 or S-phase arrest (29,30). Cyclin D1 overexpression has also been demonstrated to induce cell proliferation and has been be associated with genomic instability in breast cancer, which may contribute to oncogenesis $(31,32)$. Therefore, sustained G1 arrest, which is initially triggered by downregulation of cyclin D1, depends on p21 expression (33). These results indicate that BPs inhibit MCF-7 cell growth via cell cycle arrest.

Apoptosis may be induced via several mechanisms, including alteration of the intracellular mitochondrial pathway (34). In the present study, BPs were identified to induce ROS formation, 

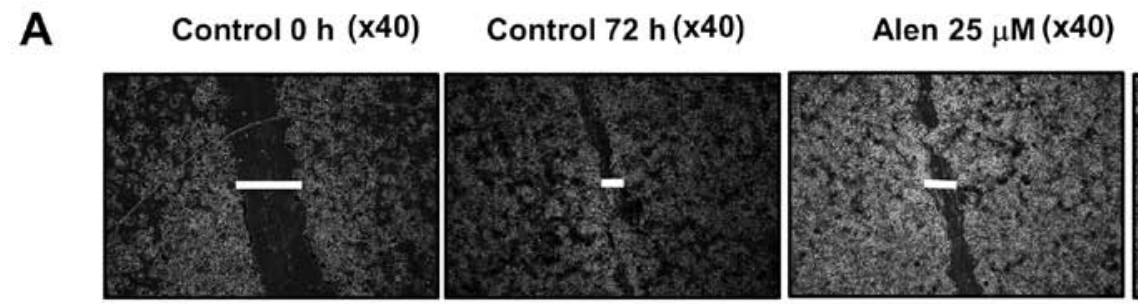

Alen $50 \mu \mathrm{M}(\mathbf{x} 40)$
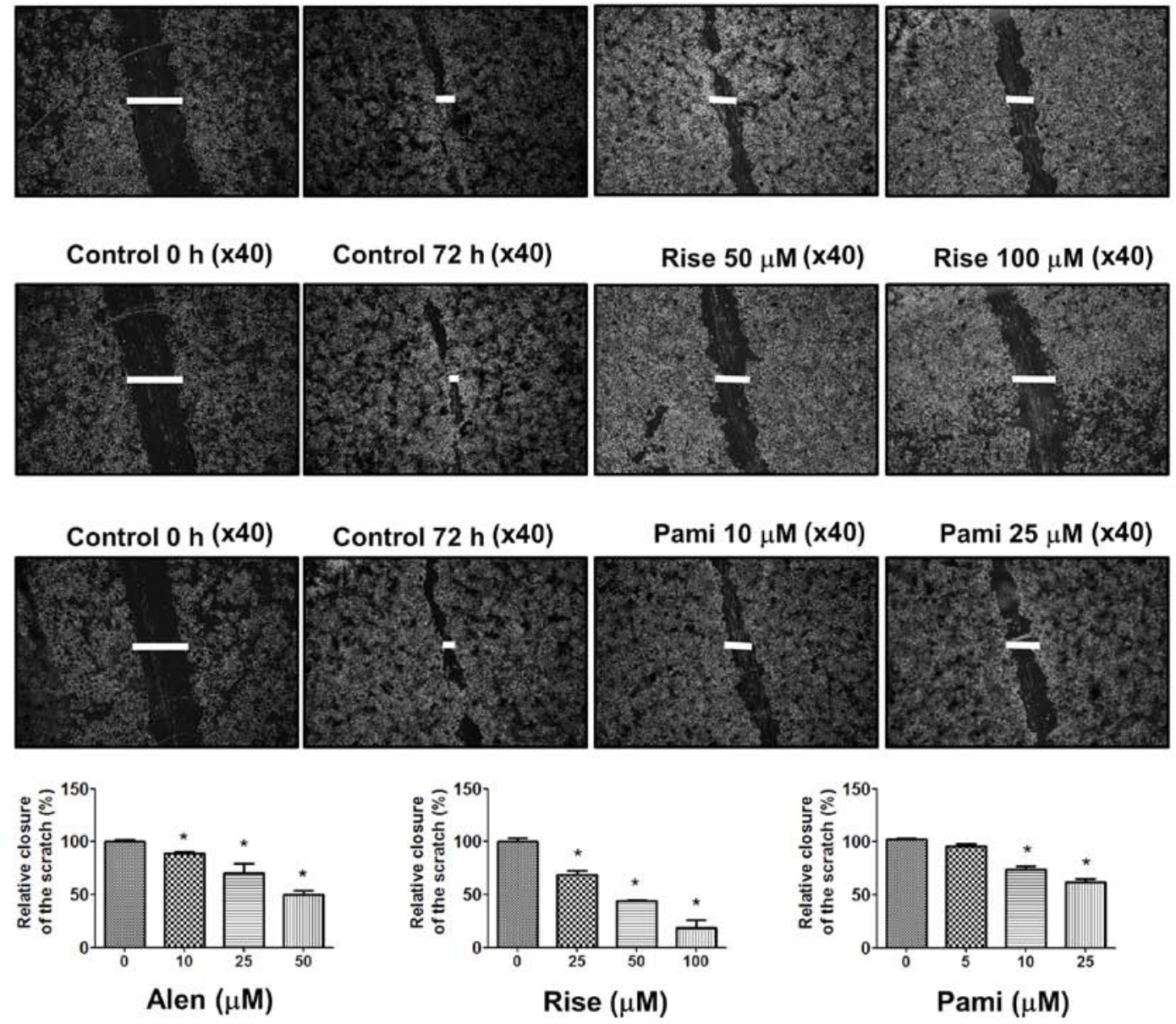

B

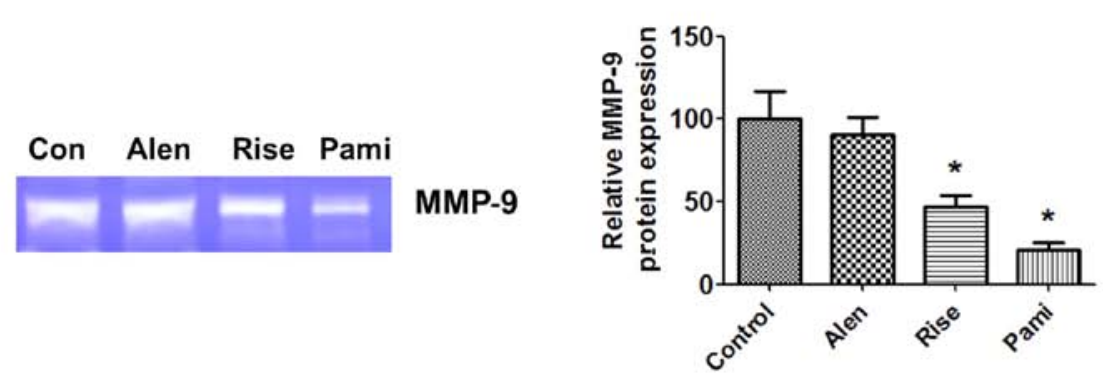

C

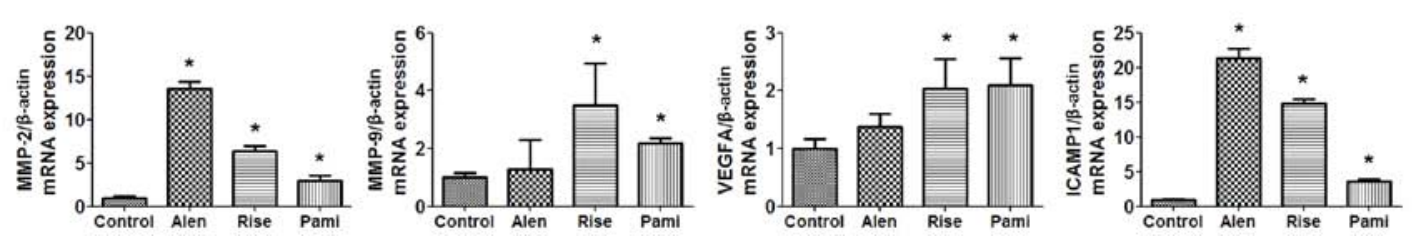

Figure 7. Effects of BPs on MCF-7 cell migration. (A) MCF-7 cells were scratched using $0.2 \mathrm{ml}$ pipette tips and treated with various concentration of BPs for $72 \mathrm{~h}$. Cell migration was monitored using phase contrast microscopy (magnification, $\mathrm{x} 40$ ). Quantified cell migration is presented as the percentage of wound closure at 72 h. (B) Effects of BPs on MMP-9 expression levels in conditioned media analyzed by gelatin zymography. (C) Cells were treated with $250 \mu \mathrm{M}$ alendronate, $250 \mu \mathrm{M}$ risedronate and $100 \mu \mathrm{M}$ pamidronate for $24 \mathrm{~h}$ and MMP-2, MMP-9, VEGFA and ICAM1 mRNA expression levels were determined by reverse transcription-quantitative polymerase chain reaction. Data are presented at the mean \pm standard error of the mean from three independent experiments with a duplicate in each experiment. "P $<0.05$ vs. control group. Alen, alendronate; Rise, risedronate; Pami, pamidronate; MMP, matrix metallopeptidase; VEGFA, vascular endothelial growth factor; ICAM1, intracellular adhesion molecule 1; BP, bisphosphonate.

increase caspase-3 activity and decrease mitochondrial function. Furthermore, apoptotic cell death, caspase-3 expression and cytochrome c expression were substantially increased following BP treatment. In summary, the results suggest that
BP-induced antiproliferative effects and induction of apoptosis in MCF-7 cells may be caused by ROS formation, and associated DNA damage and alteration of mitochondrial function. Senaratne et al (35) have previously demonstrated that other 
BPs significantly increase cell apoptosis in breast cancer cell lines. In this previous study, zoledronate was identified as the most potent BP, increasing the proportion of cells with morphological features characteristic of apoptosis, including fragmented chromosomal DNA, and it is associated with a downregulation of B-cell lymphoma 2 protein and proteolytic cleavage of poly (ADP-ribose) polymerase (35). Furthermore, Rachner et al (21) demonstrated that zoledronate induces breast cancer cell apoptosis by inducing TRAIL expression and enhancing the TRAIL/OPG ratio in TRAIL-sensitive MDA-MB-231 cells. Ebert et al (36) identified that ApppI expression increases following treatment with zoledronate to a greater extent compared with risedronate and alendronate, and this increase may lead to cancer cell apoptosis in MDA-MB-231 cells; however, BPs were revealed to suppress cell viability with minor effects on apoptosis. In summary, these studies indicate that BPs exert direct anticancer effects by inducing cancer cell apoptosis via several mechanisms; however, the precise mechanisms of BPs on cancer cell apoptosis require further investigation in future studies.

Cancer cell adhesion, invasion and metastasis are essential steps in the metastatic process, which enable cancer cells to establish persistence at the site of metastasis (37). Inhibition of the mevalonate pathway by statins and BPs is thought to impair the adhesive abilities of circulating cancer cells and thereby impact their metastatic potential (38). Treatment with statins has been demonstrated to cause a concentration-dependent decrease in cholangiocarcinoma KKU-100 cell migration (22). As cancer cell migration also requires digestion of the basement membrane by protease enzymes, this step in the metastatic cascade represents a potential target for reduction and/or inhibition (37). BPs inhibit the activity of several MMPs with $\mathrm{IC}_{50}$ values in the range of $50-150 \mu \mathrm{M}(39,40)$. The present study identified that the three tested BPs decreased cancer cell migration in a dose-dependent manner. Similar findings have been reported by Stearns and Wang (41), who demonstrated that alendronate reduces cellular secretion of MMP-2 and MMP-9 in PC3 prostate cancer cells. Rac1 and CDC42 are both required by migrating cells, and they act downstream of the mevalonate pathway (42). Statin- and BP-induced inhibition of the mevalonate pathway therefore inhibits cancer cell migration.

All three BPs tested in the present study exhibited cytotoxic activity against human breast cancer MCF-7 cells. This activity was partly attributed to cell cycle arrest and the induction of apoptosis. The BPs also inhibited breast cancer progression by inhibiting cyclin D1 expression and inducing p21, caspase-3 and cytochrome cexpression. Finally, the BPs were identified to induce breast cancer cell apoptosis by stimulating ROS formation and caspase-3 activity, and by decreasing mitochondrial function. Additionally, BPs inhibited cancer cell migration by suppressing MMP-9 expression in the culture medium. The aforementioned findings indicate that BPs possess promising activities against MCF-7 breast cancer cells and may represent a new approach for breast cancer therapy. Caution regarding the concentration of BPs used is required as permanent exposure to high doses of BPs induces apoptosis in both tumor cells and osteogenic precursors (43). However, high concentrations are required as the cellular uptake of BPs is poor in cells other than macrophages and osteoclasts, which has been described for zoledronate in ovarian cancer cells $(36,44)$.
In conclusion, alendronate, risedronate and pamidronate demonstrated cytotoxic and antimigratory activity against human breast cancer cells by inducing cell cycle arrest and increasing cancer cell apoptosis. All BPs suppressed breast cancer MCF-7 cell progression by inhibiting cyclin D1 and inducing p21, caspase-3 and cytochrome c expression. Furthermore, BPs were identified to induce ROS formation and caspase-3 activity, and decrease mitochondrial function. BPs decreased cancer cell migration via a reduction of MMP-9. In summary, these results indicated that BPs may potentially serve as candidates for breast cancer therapy and deserve to be further investigated in future studies.

\section{Acknowledgements}

Not applicable.

\section{Funding}

This study was financially supported by the Office of the Higher Education Commission (grant no. 2559A10962004), the Thailand Research Fund (grant no. MRG6080071) and the National Research Council of Thailand (grant no. 2559A10902073).

\section{Availability of data and materials}

The datasets used during the current study are available from the corresponding author on reasonable request.

\section{Authors' contributions}

BB and SB designed the study. BB performed the research and wrote the manuscript. All authors analyzed the data and were involved in writing the manuscript. BB and SB read and approved the manuscript and agree to be accountable for all aspects of the research in ensuring that the accuracy or integrity of any part of the work are appropriately investigated and resolved.

\section{Ethics approval and consent to participate}

Not applicable.

\section{Patient consent for publication}

Not applicable.

\section{Competing interests}

The authors declare that they have no competing interest.

\section{References}

1. Gnant M and Clézardin P: Direct and indirect anticancer activity of bisphosphonates: A brief review of published literature. Cancer Treat Rev 38: 407-415, 2012.

2. Labropoulou VT, Theocharis AD, Symeonidis A, Skandalis SS Karamanos NK and Kalofonos HP: Pathophysiology and pharmacological targeting of tumor-induced bone disease: Current status and emerging therapeutic interventions. Curr Med Chem 18: 1584-1598, 2011 
3. Fleisch H: Development of bisphosphonates. Breast Cancer Res 4: 30-34, 2002.

4. Rogers MJ, Gordon S, Benford HL, Coxon FP, Luckman SP, Monkkonen J and Frith JC: Cellular and molecular mechanisms of action of bisphosphonates. Cancer 88: 2961-2978, 2000.

5. Clezardin P: Potential anticancer properties of bisphosphonates: Insights from preclinical studies. Anticancer Agents Med Chem 12: 102-113, 2012.

6. Jagdev SP, Coleman RE, Shipman CM, Rostami HA and Croucher PI: The bisphosphonate, zoledronic acid, induces apoptosis of breast cancer cells: Evidence for synergy with paclitaxel. Br J Cancer 84: 1126-1134, 2001

7. Goffinet M, Thoulouzan M, Pradines A, Lajoie-Mazenc I, Weinbaum C, Faye JC and Séronie-Vivien S: Zoledronic acid treatment impairs protein geranyl-geranylation for biological effects in prostatic cells. BMC Cancer 6: 60, 2006.

8. Koshimune R, Aoe M, Toyooka S, Hara F, Ouchida M, Tokumo M, Sano Y, Date H and Shimizu N: Anti-tumor effect of bisphosphonate (YM529) on non-small cell lung cancer cell lines. BMC Cancer 7: 8, 2007.

9. Ou YJ, Chiu HF, Wong YH and Yang YH: Bisphosphonate use and the risk of endometrial cancer: A meta-analysis of observational studies. Pharmacoepidemiol Drug Saf 25: 1107-1115, 2016.

10. Passarelli MN, Newcomb PA, LaCroix AZ, Lane DS, Ho GY and Chlebowski RT: Oral bisphosphonate use and colorectal cancer incidence in the Women's Health Initiative. J Bone Miner Res 28 2043-2048, 2013.

11. Guo RT, Cao R, Liang PH, Ko TP, Chang TH, Hudock MP, Jeng WY, Chen CK, Zhang Y, Song Y, et al: Bisphosphonates target multiple sites in both cis- and trans-prenyltransferases. Proc Natl Acad Sci USA 104: 10022-10027, 2007.

12. Mönkkönen H, Auriola S, Lehenkari P, Kellinsalmi M, Hassinen IE, Vepsäläinen J and Mönkkönen J: A new endogenous ATP analog (ApppI) inhibits the mitochondrial adenine nucleotide translocase (ANT) and is responsible for the apoptosis induced by nitrogen-containing bisphosphonates. Br J Pharmacol 147: 437-445, 2006.

13. Luckman SP, Hughes DE, Coxon FP, Graham R, Russell G and Rogers MJ: Nitrogen-containing bisphosphonates inhibit the mevalonate pathway and prevent post-translational prenylation of GTP-binding proteins, including Ras. J Bone Miner Res 13: 581-589, 1998

14. Wada A, Fukui K, Sawai Y, Imanaka K, Kiso S, Tamura S, Shimomura I and Hayashi N: Pamidronate induced anti-proliferative, apoptotic, and anti-migratory effects in hepatocellular carcinoma. J Hepatol 44: 142-150, 2006.

15. Coxon JP, Oades GM, Kirby RS and Colston KW: Zoledronic acid induces apoptosis and inhibits adhesion to mineralized matrix in prostate cancer cells via inhibition of protein prenylation. BJU Int 94: 164-170, 2004.

16. Wakchoure S, Merrell MA, Aldrich W, Millender-Swain T, Harris KW, Triozzi P and Selander KS: Bisphosphonates inhibit the growth of mesothelioma cells in vitro and in vivo. Clin Cancer Res 12: 2862-2868, 2006.

17. Denoyelle C, Hong L, Vannier JP, Soria J and Soria C: New insights into the actions of bisphosphonate zoledronic acid in breast cancer cells by dual RhoA-dependent and -independent effects. Br J Cancer 88: 1631-1640, 2003.

18. Qie S and Diehl JA: Cyclin D1, cancer progression, and opportunities in cancer treatment. J Mol Med (Berl) 94: 1313-1326, 2016.

19. Vega FM and Ridley AJ: Rho GTPases in cancer cell biology. FEBS Lett 582: 2093-2101, 2008.

20. Yoshida T, Zhang Y, Rivera Rosado LA, Chen J, Khan T, Moon SY and Zhang B: Blockade of Rac1 activity induces G1 cell cycle arrest or apoptosis in breast cancer cells through downregulation of cyclin D1, survivin, and X-linked inhibitor of apoptosis protein. Mol Cancer Ther 9: 1657-1668, 2010

21. Rachner TD, Singh SK, Schoppet M, Benad P, Bornhäuser M, Ellenrieder V, Ebert R, Jakob F and Hofbauer LC: Zoledronic acid induces apoptosis and changes the TRAIL/OPG ratio in breast cancer cells. Cancer Lett 287: 109-116, 2010.

22. Buranrat B, Senggunprai L, Prawan A and Kukongviriyapan V: Simvastatin and atorvastatin as inhibitors of proliferation and inducers of apoptosis in human cholangiocarcinoma cells. Life Sci 153: 41-49, 2016

23. Livak KJ and Schmittgen TD: Analysis of relative gene expression data using real-time quantitative PCR and the 2(-Delta Delta C(T)) method. Methods 25: 402-408, 2001
24. Porter AP, Papaioannou A and Malliri A: Deregulation of Rho GTPases in cancer. Small GTPases 7: 123-138, 2016.

25. Orgaz JL, Herraiz C and Sanz-Moreno V: Rho GTPases modulate malignant transformation of tumor cells. Small GTPases 5 e29019, 2014

26. Mahtani R and Jahanzeb M: Bisphosphonates as anticancer therapy for early breast cancer. Clin Breast Cancer 10: 359-366, 2010.

27. Sahai E and Marshall CJ: RHO-GTPases and cancer. Nat Rev Cancer 2: 133-142, 2002.

28. Cayrol C, Knibiehler M and Ducommun B: p21 binding to PCNA causes G1 and G2 cell cycle arrest in p53-deficient cells. Oncogene 16: 311-320, 1998.

29. Brugarolas J, Chandrasekaran C, Gordon JI, Beach D, Jacks T and Hannon GJ: Radiation-induced cell cycle arrest compromised by p21 deficiency. Nature 377: 552-557, 1995.

30. Niculescu AB III, Chen X, Smeets M, Hengst L, Prives C and Reed SI: Effects of p21(Cip1/Waf1) at both the G1/S and the G2/M cell cycle transitions: $p R b$ is a critical determinant in blocking DNA replication and in preventing endoreduplication. Mol Cell Biol 18: 629-643, 1998.

31. Lung JC, Chu JS, Yu JC, Yue CT, Lo YL, Shen CY and Wu CW: Aberrant expression of cell-cycle regulator cyclin D1 in breast cancer is related to chromosomal genomic instability. Genes Chromosomes Cancer 34: 276-284, 2002.

32. Nelsen CJ, Kuriyama R, Hirsch B, Negron VC, Lingle WL, Goggin MM, Stanley MW and Albrecht JH: Short term cyclin D1 overexpression induces centrosome amplification, mitotic spindle abnormalities, and aneuploidy. J Biol Chem 280: 768-776, 2005.

33. Sandor V, Senderowicz A, Mertins S, Sackett D, Sausville E, Blagosklonny MV and Bates SE: P21-dependent g(1)arrest with downregulation of cyclin D1 and upregulation of cyclin E by the histone deacetylase inhibitor FR901228. Br J Cancer 83: $817-825,2000$

34. Ghavami S, Hashemi M, Ande SR, Yeganeh B, Xiao W, Eshraghi M, Bus CJ, Kadkhoda K, Wiechec E, Halayko AJ and Los M: Apoptosis and cancer: Mutations within caspase genes. J Med Genet 46: 497-510, 2009.

35. Senaratne SG, Pirianov G, Mansi JL, Arnett TR and Colston KW: Bisphosphonates induce apoptosis in human breast cancer cell lines. Br J Cancer 82: 1459-1468, 2000.

36. Ebert R, Meissner-Weigl J, Zeck S, Määttä J, Auriola S, Coimbra de Sousa S, Mentrup B, Graser S, Rachner TD, Hofbauer LC and Jakob F: Probenecid as a sensitizer of bisphosphonate-mediated effects in breast cancer cells. Mol Cancer 13: 265,2014

37. Morrissey MA, Hagedorn EJ and Sherwood DR: Cell invasion through basement membrane: The netrin receptor DCC guides the way. Worm 2: e26169, 2013

38. Green JR: Antitumor effects of bisphosphonates. Cancer 97: 840-847, 2003

39. Boissier S, Ferreras M, Peyruchaud O, Magnetto S, Ebetino FH, Colombel M, Delmas P, Delaissé JM and Clézardin P: Bisphosphonates inhibit breast and prostate carcinoma cell invasion, an early event in the formation of bone metastases. Cancer Res 60: 2949-2954, 2000.

40. Teronen O, Heikkilä P, Konttinen YT, Laitinen M, Salo T, Hanemaaijer R, Teronen A, Maisi P and Sorsa T: MMP inhibition and downregulation by bisphosphonates. Ann N Y Acad Sci 878: 453-465, 1999

41. Stearns ME and Wang M: Alendronate blocks metalloproteinase secretion and bone collagen I release by PC-3 ML cells in SCID mice. Clin Exp Metastasis 16: 693-702, 1998.

42. Raftopoulou M and Hall A: Cell migration: Rho GTPases lead the way. Dev Biol 265: 23-32, 2004.

43. Idris AI, Rojas J, Greig IR, Van't Hof RJ and Ralston SH: Aminobisphosphonates cause osteoblast apoptosis and inhibit bone nodule formation in vitro. Calcif Tissue Int 82: 191-201, 2008.

44. Shmeeda H, Amitay Y, Gorin J, Tzemach D, Mak L, Ogorka J, Kumar S, Zhang JA and Gabizon A: Delivery of zoledronic acid encapsulated in folate-targeted liposome results in potent in vitro cytotoxic activity on tumor cells. J Control Release 146: 76-83, 2010.

This work is licensed under a Creative Commons Attribution-NonCommercial-NoDerivatives 4.0 International (CC BY-NC-ND 4.0) License. 